The University of Akron

\title{
IdeaExchange@UAkron
}

July 2018

\section{Filming the Stage: Reflections on the Historical and the Aesthetic Perspectives of an Essential Archive of the Future}

André Deridder

Université Catholique de Louvain, andre.deridder@uclouvain.be

Please take a moment to share how this work helps you through this survey. Your feedback will be important as we plan further development of our repository.

Follow this and additional works at: https://ideaexchange.uakron.edu/docam

Part of the Other Film and Media Studies Commons, Performance Studies Commons, and the Theatre History Commons

\section{Recommended Citation}

Deridder, André (2018) "Filming the Stage: Reflections on the Historical and the Aesthetic Perspectives of an Essential Archive of the Future," Proceedings from the Document Academy: Vol. 5 : Iss. 1 , Article 4.

DOI: https://doi.org/10.35492/docam/5/1/4

Available at: https://ideaexchange.uakron.edu/docam/vol5/iss1/4

This Conference Proceeding is brought to you for free and open access by University of Akron Press Managed at IdeaExchange@UAkron, the institutional repository of The University of Akron in Akron, Ohio, USA. It has been accepted for inclusion in Proceedings from the Document Academy by an authorized administrator of

IdeaExchange@UAkron.For more information, please contact mjon@uakron.edu, uapress@uakron.edu. 


\section{Introduction}

Is the stage a filmable space? Theoretically, any space can be filmed. Since the beginning, films were mostly made up of different spaces, external or internal ones, or just one which was scrutinized via a variety of shots. Audio-visual spaces are also mostly multiple. The stage, where a performance was originally created or took place, appears mostly to be single space. In contrast to this principle, audio-visual arts create new and multiple spaces. Obviously when they are shot in a studio setting, every film creates new spaces. In fact, they re-create spaces through the eye of the camera.

For performing artists, the stage is not, by any means, a neutral space, it is a highly specific space. It is a dedicated area which has its own particularities independent of its use by artists and performers. It is measurable and its dimensions are for the most part limited. Whatever form it takes, this space is an essential constituent of the performing arts. However, the stage only exists because of its hinterland. This off-stage area, which may be extended or reduced, provides the stage with an additional and exceptional dimension. The stage is also the focal point for the audience, but it could not acquire its real dimension without its hinterland. Multiple eyes are watching it.

Is it therefore possible to properly capture what is taking place on stage in an audio-visual format, knowing that the camera will replace the experience of the audience? As puerile as this question might seem, it remains at the heart of the relationship between the performing arts and the audio-visual arts. Both have evolved as a result of aesthetic changes over the years, but it is the latter which has seen major technological changes in the different media used. Filming for a TV production differs widely from the original cinema-based film.

Besides the basic question of the filmable aspects of the stage, there is its extension: how far can a stage-based film document past performances? Since the beginning of cinema, you could have expected that filmed performances would become the ultimate way to capture an art form that is not only in essence ephemeral, but also highly visual too. In French, the word captation [video recording], refers explicitly to capturing images. Recorded images are then caught or captured. Could they save the performances from oblivion or, at least, be a trusted witness of them?

Performing arts are three-dimensional and occur live on stage or in an unlimited space. On the other hand, audio-visual arts are primarily two-dimensional and displayed mostly on screens. Although different degrees of transformation or adaptation are available, the transfer from a specific space implies direct aesthetical questions for performing artists and methodological questions for those studying performing arts and those archiving materials to document them. 
Before moving pictures were available in the late 19th century, historians, critics and aesthetical analysts, could only refer to a few external sources, if they existed at all, to partially document performances. Only sketches, drawings or more recently photographs could provide a picture of the stage. Manuscripts and edited texts, musical scores and librettos were once the most complete record of past performances, from the opening scene to the falling curtain. Therefore the study of the text dominated historical research in the performing arts for a long time.

Until the appearance of early filming techniques, only a narrative and various archive artefacts were available, in a highly limited sense. Regardless of whether this gave the right or wrong impression, what is sure is that they gave an incomplete picture of a performance or a show which took place in the past. As the film lasts virtually the same length of time as the actual performance, filming the stage could be perceived as the ultimate archive. For a show which lasts an hour and a half, you get an hour and a half of archive material.

Confusion between the subject and its image may emerge. Is the film the performance, the ultimate record of the show? The answer is obvious as the film is not the performance. It is an audio-visual product which possesses its own raison d'être. Even if the film is made up of various parts shot at different moments or places, this confusion may arise since a stage-based film appears as a finished product. In the 20th century, the development of audio-visual art techniques offered an opportunity to keep a valuable record of performances. Filming the stage was possible to a limited extent for the cinema or for the TV.

\section{Historical Perspective: Learning from 20th-Century Experiences}

The relationship between the performing arts and audio-visual arts started as soon as the latter emerged and began, in fact, to conquer the environment occupied by the former. The different performing arts, from ballet, opera, to dance theatre productions, ruled unchallenged, over the entertainment, recreational and artistic stages until the late 19th century. Films appear at the peak of the development of the Société du spectacle [The Society of the spectacle] which had grown mostly in capitals or larger urban economic centres. Never has human history known such a development of the performing arts. It enlightened not only the boulevards of the imperial or national capitals, like London, Paris, Berlin or Vienna, but also reached cities aspiring to resemble these high-profile models. Films were welcomed as an additional entertainment among such a varied choice of shows.

From this moment on, both performing and visual arts had to live, share and compete together, for better or for worse.

But despite the basic differences, both provided entertainment, artistic or otherwise.

The relationship between the performing arts and the recording of them has, in fact, not always been an easy one. As historical evidence, filming in general or 
filming the stage in particular, had the very same purpose as performing arts: to be performed in front of an audience, on screen, or on stage. This was true for a long time and long before considering any archiving intentions.

The first filmmakers of stage related arts did not do it for reasons of conservation or broadcasting, but to feed the massive demand for cinema. Many early films were adaptations of theatrical plays, such as the works of Shakespeare which were translated into different languages and spread to many countries. The literary works of the Bard of Avon were considered the surest and safest literary references that could be dramatized on film as his plays were well-known throughout the Western world. There was a considerable market at that time for silent films. Using well-known plays ensured that the audience would be more accepting of a new type of medium: the big screen.

The performing arts supplied in the early days of cinema not only stories or scripts, but also actors and performers. Recorded in customised settings in studios, some of the original cast were used in the films.

Silent films were not only inspired by historical plays, but a diverse range of performing arts. Mime, circus acts, contortionists and acrobats are just a few examples of the many films made for the cinema to appear in the catalogues of the first film companies (such as in Gaumont, France). Other than details on the sets, the movements and the humorous aspects, very little information remains today about this films. In particular very little is known about the live performances, if they even existed in the same format.

From the development of film as an art and the growth of the film industry, the question of the relationship between performing and audio-visual arts torments "creators" as well as, later on, many historians. For audio-visual creators, many debates surround the idea that cinema must absolutely emancipate itself from the stage and its theatricality. The stage had to disappear as the cinema explored more and more its potential to create new spaces, which were mostly impossible to achieve on stage.

For performing artists and creators, including some which occasionally or regularly turned to the audio-visual arts, filming the stage was not perceived as easy and many considered it as a failure, because something would always be lost. For many stage or theatre directors, there was a long-standing belief that filming a performance on stage only served to preserve a distorted record of the original production. Creators hardly recognised their creations from the creatures reproduced on film. Quoted maybe too many times, the words of the French stage director Roger Planchon (1931-2009) resonate as a death sentence: "Recording the best shows on film, even with care, is the worst thing you can do to theatre and cinema, both of them lose their souls". Filming the stage acquired the image of a Faustian pact with the devil. A lost cause, for a performing artist or a group, with financial risks and a high risk of losing their soul, or reputation. 
Filming theatre, dance, circus or the opera becomes a highly risky challenge: to be able to live up to something that is truly un-filmable because of its living nature. These philosophical or psychological concerns should also be considered within the framework of the competitive environment which emerged with the appearance of films. Audio-visual professionals had acquired the techniques and skills which placed then in direct competition with directors and choreographers. No sooner had the stage director [metteur en scène] become the undisputed leader on stage a new competitor, the film-maker, soon to be called producer [réalisateur], stepped in with new skills and new technologies.

With the emergence of televisual techniques and the multiplication of TV screens at home, the evolution of the relationship between the stage and film was still very slow, but represents another milestone in the history between the two visual arts. From the start, the purpose of the small screen was somewhat the same as the big one, the cinema: to provide entertainment. However target audiences were larger by far as it could reach almost every household. Many TV productions were designed to be highly educational too. In their early days, national broadcasters, rather like the radio stations they would gradually usurp, would broadcast live performances. As such, it was closer to the essence of performing arts. Once again, the final idea behind filming the stage was also to present the show, neither archiving it nor documenting it. But several TV programmes proved successful by the number of productions and popularity. Their longevity was determined by TV ratings.

In the United Kingdom, before WWII, the BBC pioneered the production of more than 300 live shows, mainly staged for broadcasting purposes only. Popularizing dramas was the driving force behind these productions. The size of the equipment, the lighting and the sound recordings often required customised studios. However, technical and organisational difficulties prevented the further development of live recordings. Filming the stage in the building where the stage is actually located represented an expensive challenge with an uncertain outcome.

Delayed broadcasts then became the standard for television production. In France, a well-known popular state-funded TV programme, Au théâtre ce soir [On stage this evening], started in 1965 and lasted for more than 20 years. The origin and the development of this regular programme emerged by chance. The year before it started, Belgian public television, called RTB at the time, recorded a play at the Théâtre du Vaudeville in Brussels. It was a light comedy, called "La bonne planque" (The best hideout), which had been performed on stage in Paris in 1962 and in which the highly popular French actor André Bourvil had acted. Due to a strike by the technicians at French TV, this recorded version was borrowed, in a rush, from Belgium and broadcast in France, on delayed broadcast, in February 1965. The success far exceeded the initial expectations of the programmers. Taking them completely by surprise, it was decided to create a regular programme, 
broadcast at prime time, on Friday or Saturday evening. The idea, as the title of the series suggested, was to re-create the theatre atmosphere at home. Plays were recorded mostly at the Théâtre Marigny, next to the Champs-Élysées, or, sometimes at the Théâtre Édouard-VII, also in Paris. The City of Light offered several stages but the use of these two theatres would have a similar impact in French homes as Broadway or West End theatres would have on households in Idaho or in Derbyshire. It was more the image of how theatre life in Paris should be which was presented, rather than how it really was. Nevertheless the stage had regained some ground thanks to the fact that recording techniques were evolving with the appearance of video recording.

Despite the dominance of popular drama in the repertory, it is obvious that the action in taking place on a theatre stage. However, the format was always the same. In every the recording the introduction to the play starts with, in several shots, details of the building, focusing on theatre iconography, and the audience taking their seats. It is followed by a single overall shot, presenting the stage set, after the curtain has risen. After this overall shot framing the stage, it alternates, for the rest of the show, between full shots, medium shots and close-ups of the actors. At the end of the show, after the actors have taken their bows and been presented, the curtain falls and once more there is an overall shot of the stage set. This is followed by additional shots focusing on the audience leaving the building. The show is over on stage and also on the small screen.

For these productions, filming lasted several days and most parts of the films were not recorded in the presence of an audience. Laughing could be added, at a postproduction level, on certain parts to resemble more the sitcoms which were later to follow, rather than a performance. The main reasons were the unpredictability of the audience as well as the sound recording and lighting of the stage during the show in a building which was not designed for such a recording. Such productions were disregarded by most performing artists, dismissing them as "theatre in a tin can". The remarks of French theatre director Antoine Vitez (19301990) are clear and testify that the situation has evolved little: "Audio-visual and television do not interest me. Besides, television is not an art. It is only technology". Unfortunately, TV productions of performing arts poorly document shows which were customised to fit the small screen rather than the stage.

Besides a few successful cases of stage-based films, mainly due to personal and professional cooperation between stage and film directors, cinema and TV productions of stage-based performances revealed more of the history of audiovisual arts than on performing arts which they were supposed to focus on.

In this difficult relationship, the economic dimension should not be ignored as the cost of stage-based productions was high and did not have the same guaranteed long-term returns as a film's, especially after the emergence of byproducts, such as video tapes and then DVDs. This could explain why, by the end 
of the $20^{\text {th }}$ century, cinema productions favoured adaptations of theatre-based works rather than filming performances on the stage. This was the case of successful cinema productions performed around famous popular actors such as L'avare [The Miser] by Molière, with Louis de Funès (1980), Shakespearian films directed by Kenneth Branagh in the late 1980s or Cyrano de Bergerac by Edmond Rostand, with Gérard Depardieu (1990). In these drama-based films, the stage has definitely vanished, even if some anecdotal sequences refer to the original space.

\section{Aesthetical Perspectives: Exploring New Ways}

How can the stage still have a place on the screen? Thanks to the screen, both big and small, it had almost disappeared. By the turn of the $21^{\text {st }}$ century, the stage had become a non-existent space as artistic prejudices, limited technologies and the rarely admitted competition between the arts had prevented recordings from evolving beyond this step.

However, a new generation of technicians and directors has emerged, supported by new digital technologies, new recording techniques, and, most of all, new broadcasting media. The situation has evolved rapidly. The volume of motion pictures of all types has since exploded, encouraged by the dramatic fall in production costs, access to recording equipment and high levels of exposure via various video hosting services.

Since 2000, live shows have again become widely available through a network of cinemas, such as The Metropolitan Opera in New York (December 2006), the National Theatre in London (2009) and la Comédie Française in France (2016). Additionally, recorded shows are available on-line, in their entirety or in part, through streaming platforms or official websites. Not least, many performing artists or groups record extracts from their productions to advertise them in the form of trailers. This was not previously economically viable as broadcasting on TV was far too expensive and the impact less than certain. There is now a plethora of moving pictures and the question of archiving standards appears to be also vital as the producers are neither cinema studios, nor TV companies.

Meanwhile the question remains on how not to confuse the performance as it was actually on stage and the final filmed product, now widely available on the internet. Do these new types of images document the performances better than TV and cinema productions?

Actually, the multitude of recordings offers a new opportunity to consider them as valuable archive pieces. The cinema and TV production of a staged-based performance was usually a one-off. When multiple recordings are available the confusion between the image and the object is avoidable as it allows a comparative methodology which makes motion-pictures highly useful for documenting 
performances. Lower production costs allow, in some cases, to hold two, or more, different recordings of the same play.

The Belgian public television corporation, RTBF, is legally required to record and broadcast a number of plays every year. In 2013, they broadcast Dialogue d'un chien avec son maître sur la nécessité de mordre ses amis [Dialogue of a dog with his master on the need to bite his friends] by the Belgian author JeanMarie Piemme, which premiered on stage in October 2007 at the Théâtre National de la Communauté française (Brussels). The play was directed by Philippe Sireuil and the film by Coralie Pastor. To meet TV standards, the set and the movements of the original actors were modified, including the use of colourful fairy lights on the black curtains which surrounded the stage. Tracking shots and camera movements were included in the film production. Several cameras were needed for the various scenes and parts were recorded without the presence of an audience. Sequence selection and camera viewpoints, with future mounting and editing in mind, proved to be essential steps to take before the actual filming began. To acknowledge the theatricality of the show, the film's director included a very short sequence at the beginning of the film. Once the main character had come on stage, a few shots were taken from behind his back, revealing the presence of the audience from a point of view which no one in the audience could have had during the real show. If the TV show meets the quality required for the size of a small screen, it still twists the perception one could have had of the show on stage.

Around the same time, two other films were produced, about the same play, one by the technical team of the Théatre national and the other by the Archives et Musée de la Littérature (AML) in Brussels. While the Théâtre National technical team aimed to document the show with regard to the tour which was planned, the other intended to keep a recording of the show based on the text of the Belgian author. In both cases, a single camera revealed a single point of view. The best documenting point of view is located at the crossing point of these three productions. Each complements the other.

One should be cautious about looking at these productions on their own as they each have their own history. The challenge of this multiple environment is that none of these films provides a satisfactory replication of the show. All of these artefacts have to be considered together to document, one way or another, the existence of the show. Additionally, multiple records require that production information should be properly saved and archived: pre-performance scenarios, scripts, intention notes, drafts, etc. These documents will prove vital to understanding the decisions which were taken. These documents are, by their nature, not motion pictures and rarely accompany the films. They should be considered as a whole when it comes to documenting performances. Archiving them should be a priority as much as selecting long-lasting standards for storing the films. 


\section{Typology of Moving Pictures}

Today, far more moving pictures are being produced than at any time in the history of performing arts. Complete films, rehearsal materials, trailers are produced by various sources. Brought together they represent the greatest opportunity for a better understanding of an art from which is ephemeral by nature. But their sheer quantity also represents a challenge that most archivists can identify with.

A common typology describing and naming moving images produced on and around the stage, before, during or after the performances, would assist research, as it would indicate production intent. Different criteria could be considered in order to recognise the purpose of the images. Standards developed by films archives could fall short of these categories by the nature of the subject.

In addition to the metadata which should accompany the images, several criteria could be established in combining parameters such as the date and time of the recordings (before, during or after the performances), the final products (rehearsal or promotional materials, trailers, complete or partial performances), the production origins (internal or external), the editing process, as well as the presence or absence of an audience. Properly named according to a set of combined criteria could prove valuable for researchers aiming to use these recordings as an archive.

\section{Conclusion}

New technologies, from recording to broadcasting, are allowing us to reconsider the place of moving images within all the artefacts which document performances. Awareness of the particularities of recording images could expand our understanding far more than TV and cinema productions of the $20^{\text {th }}$ century have ever allowed us to do. Archiving requirements, format standards and good practice could prove valuable in this fast developing field. To consider the development of an appropriate language to describe a particular matter should not be seen as a step backwards. The use of a common language has, so far, not been proven as a waste of time, especially when it aims to broaden our understanding of a single space the stage - seen through multiple screens, whatever their size.

\section{References}

Aubenas, J. (2006). Filmer la danse. Brussels, Belgium: La Renaissance du Livre. Bablet, D. (1981). Filmer le théâtre. Louvain-la-Neuve, Belgium: Cahiers Théâtre Louvain.

Blaukopf, K., Marsolais, G., Dahlberg, H., \& Frank, A. (1973). Théâtre et télévision. Paris, France: UNESCO. 
Chabrol, M., \& Karsenti, T. (2013). Théâtre et cinéma: le croisement des imaginaires. Rennes, France: Presses Universitaires de Rennes.

Davies, A. (1988). Filming Shakespeare's plays: the adaptations of Laurence Olivier, Orson Welles, Peter Brook and Akira Kurosawa, Cambridge: Cambridge University press.

Dupuis, X., \& Sagot-Duvauroux, D. (1984). Les relations spectacle vivant et audiovisuel: premières considérations. Paris, France : Ministère de la Culture, Service des Études et Recherches.

Hoffert, Y., \& Kempf, L. (2010). Le théâtre au cinéma: adaptation, transposition, hybridation. Nancy, France: Presses Universitaires de Nancy.

Marill, A. H., \& Leonard, W. T. (1993). More theatre: Stage to screen to television, Metuchen: Scarecrow Press.

Tesson, C. (2007). Théâtre et cinéma. Paris, France: Cahiers du Cinéma.

Viviani, C. (2015). Marcel Achard entre théâtre et cinéma. Caen, France: Presses Universitaires de Caen. 